\title{
A Cointegration Analysis of Money Supply and Saudi Stock Price Index
}

\author{
Saud Almutair ${ }^{1}$ \\ ${ }^{1}$ Economics Department, College of Economics and Administrative Sciences, Al-Imam Muhammad Ibn Saud \\ Islamic University, Kingdom of Saudi Arabia \\ Correspondence: Saud Almutair, Economics Department, College of Economics and Administrative Sciences, \\ Al-Imam Muhammad Ibn Saud Islamic University, Kingdom of Saudi Arabia. E-mail: s.mutair@hotmail.com
}

Received: March 19, 2015

Accepted: April 7, 2015

Online Published: April 25, 2015

doi:10.5539/ijef.v7n5p153

URL: http://dx.doi.org/10.5539/ijef.v7n5p153

\begin{abstract}
This paper aims to use the Cointegration to analyze the relationship of money Supply and Saudi Stock Price Index (SSPI) using different measure of money supply M1 and M2 and different time series; annual data from 1985 until 2012 and monthly data from 2000 until 2013. The goal is to discover the relationship between SSPI and MS and to identify the long run as well as the short run causality using Vector Error Correction Model (VECM). The most important finding is the confirmation of long run relationship between M1 and SSPI as well as M2 and SSPI in both monthly and yearly data. The study has found that the long run causality is running from SSPI to M1 for annual data but not the other way around. This finding supports the Post-Keynesian theoretical approach which indicates the endogeneity of MS. Moreover, the result is consistent with efficient stock markets hypothesis since MS does not affect the SSPI in the long run. The implication of this result is that Saudi Arabian Monetary agency as well as commercial banks cannot affect the Saudi Stock prices through change in MS. This paper assures bidirectional short run causal relationship (or feedback effect) between SSPI and M1 by using annual data. The paper has not found neither long run nor short run causal relationship between SSPI and M2 with annual data. Furthermore, the study could not prove any long run or short run causality between M1 and SSPI or between M2 and SSPI through the use of monthly data.
\end{abstract}

Keywords: cointegration, efficient stock markets hypothesis, Saudi stock market, money supply, VECM

\section{Introduction}

The stock market plays a major role in providing capital requirement of the firms. It helps to issue stocks to the general public which is one of the most cost effective ways for long run fund requirements. Many economists find that the growth as well as development of a nation depends on the level of investments which requires long run finance. As a result, the stock market plays a crucial role of economic growth and development (Aydemir \& Demirhan, 2009). Stock market participates in distributing the wealth of nation by widening the ownership of public company stocks. Any investor can own stocks of publicly listed companies through the purchase of shares from stock market. The percentage of ownership in a company depends on the number of the shares that you own. The significance of "good" performance of the stock market is self-evident. History has informed us that a collapse of stock prices can cause major disturbances in the standard of living of many. On the other side, the strength of a stock market can cause a major positive effect on the economy through its effect on real economic activities. The performance of the stock market depends on many important determinants. It is highly sensitive to a country's economic and political situation. If the economic condition of a country is doing well, then the stock market usually gives high returns and vice versa. The stability of the political condition of the nation is also a significant factor that affects stock market performance. Thus the political stability of Saudi Arabia and the rapid growth of oil revenue for the last ten years contribute to the development of the Saudi Stock Market.

Monetary policy is one of the most effectual tools that a central bank has under its control. The central bank uses monetary policy more often to induce a desired level of change in real economic activities. These changes in monetary policy have an important effect on the stock market. Indeed, the economic theory confirms a relationship between money supply and stock price index. However, there are different views regarding the nature of the relation and the causality issue. This study aims to discover the relationship between money supply and Saudi Stock Price Index and to know the direction of the causality between them. It is also important to find 
out the implication of the result for the endogeneity of money supply and the stock market efficiency in Saudi Arabia. The importance of the study is to find out whether the money supply is exogenous or endogenous. Also it is important to know if the monetary policy could affect the stock prices. This study proceeds as follow: In Section II, literature review that is relevant to the topic. The theoretical model is discussed in Section III. It will be followed by Section IV which deals with data and empirical methodology. Section V is the empirical results and the paper will be concluded in Section VI.

\section{Literature Review}

According to Flannery and Protopapadakis (2002), the most important factor influencing the development of stock prices in the long run is the amount of money supply in the economy. Chromec (2006) stated that the change in money supply is one of the most important tools available to the national central banks of individual countries to influence the actual economic activity in general and stock prices in particular. Many economists, such as Poiré (2000) or Shostack (2003) think about the money supply to be the most significant macroeconomic element that affects the behavior and development of stock prices. Gupta (1974) states that the money supply can be utilized for predicting the development of stock markets. His finding confirmed that $59 \%$ of the price of stock indices can be forecasted based on the supply of money. This result is confirmed by Rapach, Wohar and Rangvid (2005) who, in their study concentrated on the prediction of stock market development by using macroeconomic factors in eleven nations. They extrapolated that the most trust worthy macroeconomic indicator for stock market projection is the interest rate which is mostly affected by money supply. Husain and Mahmood (1999) investigate the relationship between monetary expansion and stock returns in Pakistan using different type of money supply; specifically M1 and M2. Their aim was to find a connection between money supply and both short and long run changes in stock market prices. The paper finds that money supply causes changes in stock prices in the long run as well as in the short run, forecasting that the stock market is not efficient with regard to the money supply. The efficient market hypothesis does not persist. A two-stage regression model used by Maskay (2007) who looks for whether or not there is a link between money supply and stock prices. If there is, what is the direction of the link? Does stock values behave as Sellin (2001) predicts or as the real activity theorists predicts? The results of this work suggest that the theory of real activity theorists dominates Sellin's (2001) theory. The results of the study support the view of the real activity hypothesis that a positive money supply shock raises stock prices and vice versa. It also supports the opponents of Efficient Market Hypothesis that expected changes in the money supply more important than unexpected changes in determining stock values. The issues of efficiency of the stock market in Malaysia and cointegration between money supply and stock prices were studied by Habibullah and Baharumshah (1996). They found a weak efficiency and non-existent cointegration between money supply and stock values at that market. Once again Habibullah (1998), investigated the empirical link between money supply and stock prices in the Kuala Lumpur Stock Exchange (KLSE), using monthly data that span from January 1984 to September 1992. Specifically, he tested for market informational efficiency in KLSE by examining the causal link between money supply; M3 and stock prices using the cointegration technique. The consequence of Vector Error Correction Models (VECM) manifests the informational efficiency markets hypothesis cannot be accepted for the KLSE. However, he found a causal relationship between money supply and stock prices. His conclusion is money supply M3 can be a useful monetary instrument in affecting the stock market when the need arises. Some researchers dealing with the correlation and link between stock markets and the money supply are e.g. Maysami and Koh (2000) who, in the case of the Asian market concluded a positive link between money supply and the development of the Singapore stock exchange, supporting the hypothesis that a growth in the money supply will induce inflation, which causes a growth in future cash-flow and stock prices. The same result has been assured by Maysami, Howe and Hamzah (2004). They reveal a positive relationship between money supply change and stock price evolution on the Singapore stock exchange. The causality between money supply and stock markets in emerging markets was discussed by Brahmasrene and Jiranyakul (2007). Through their study of the Thai stock market between 1992 and 2003, they found a positive relation between money supply and stock values. Cagli, Halac and Taskin (2010) investigated the relationship between money supply and share values on the Turkish market. These writers did not conclude any cointegration between the two variables. The influences of the changes in macroeconomic factors (among them money supply) on the development of stock prices were studied also by Shaoping (2008), who assured strong effect of the money supply on the development of stock prices in the period between 2005 and 2007. He found a long run and stable relationship between stock prices and money supply with different measure; M0, M1 and M2. His study confirmed a positive cointegration between stock prices and money supply. As a result, the growth of money supply induces a higher price of equity shares. In other words monetary policy expansion makes stock prices to grow and, on the contrary, a contraction monetary policy causes stock prices to fall. They show how stock market variation corresponds to changes in monetary policy. Pallegedara (2012) 
investigated the dynamic links between stock market performance and the interest rates in Sri Lanka during June 2004 to April 2011. He used all stock price index in the Colombo stock exchange as a measure of stock market performance indicator and Sri Lanka Interbank Offer Rate as a measure of interest rate. He employed some conventional time series econometric techniques such as Unit root test, cointegration test), Granger-Causality test to discover the relationships between stock market index and interest rate. The findings of interest include stock market performance is the negative relationship with interest rate in the long run while no causal link is found in the short run. Furthermore, doing different measures of money supply yield different effects on stock prices? Kraft and Kraft (1977a, 1977b) conclude that the detection of lead-lag relationship between money supply and stock prices are insensitive to the choice of the definition of money supply used. However, several other empirical studies have shown that different choices of money supply measures can have different impacts on stock prices. For example, take the case of Mookerjee's (1987) study, where for Canada, the stock market is efficient with respect to narrow money supply M1, but with broad money supply M2, the results suggest that money supply is the leading indicator for stock price. Results from Thornton (1993), Ho (1983) and Jones and Uri (1987) tend to point to the conclusion that stock markets are sensitive to different measures of money supply used. Therefore, it could be can concluded that different measures of money supply used can yield different impacts on stock prices. Alshogeathri (2011) investigates the long run and short run relationships between Saudi stock market returns and eight macroeconomic variables; M1, M2 money supply, short-term interest rates, consumer price index, bank credit, world crude oil prices, exchange rate and Standard and Poor 500 index as a proxy for the influence of the US stock on the local stock market. The study uses Vector autoregression (VAR) and (GARCH) models to analyze monthly data from January 1993 to December 2009. A Johansen-Juselius cointegration test indicates a positive long run relationship between the Saudi stock price index and the M2 money supply, bank credit, and the price of oil, and a negative long run relationship with the M1 money supply, the short term interest rate, inflation, and the U.S. stock market. An estimated vector error correction model (VECM) suggests significant unidirectional short run causal relationships between Saudi stock market returns and the money supply and inflation. The VECM also finds a significant long run causal relationship among the macroeconomic variables in the system. The estimated speed of adjustment indicates that the Saudi stock market converges to the equilibrium within half a year. Granger causality tests show no causal relationship between Saudi stock market returns and the exchange rate. Kalyanaraman and Al Tuwajri (2014) testes the possibility of a long run relationship among five macroeconomic variables, consumer price index, industrial output, money supply, exchange rate, oil prices and the global stock prices proxy Standard and Poor 500 index and Saudi all share stock index. Time series analysis is applied using monthly data from January 1994 to June 2013. Application of Johansen cointegration test finds the existence of a long run relationship among the chosen variables. All macroeconomic variables are found to impact stock prices. Standard and Poor 500 index does not affect Saudi stock prices. Vector error correction model shows the presence of long run causality from the explanatory variables to the stock prices. Short run causality test finds a two-way causality between stock prices and oil prices.

\section{Theoretical Model}

Following the work of Sprinkel (1964), many studies have tried to test the respond of the stock market to growth in money supply. The relationship between money supply and stock market has been widely investigated because of the belief that the growth in money supply has significant direct influence through portfolio changes, and indirect effects through their effects on real economic activities, which in turn presumed to be the main determinants of share values. In other meaning, there are competing theories on how money supply influences stock market values. These theories tested here are the ones developed by the real activity theorists and by Sellin (2001). Sellin (2001) argues that money supply will influence share values only if the change in money supply affect anticipation about future monetary policy. He claims that a positive money supply shock will cause people to predict contraction in monetary policy in the future. The subsequent increase in bidding for bonds will drive up the current rate of interest. As the interest rate increases, the discount rates rise as well, and the present value of future earnings decreases inducing stock prices to go down. Furthermore, Sellin (2001) states that economic activities decline as a result of rise in interest rates, which further reduce stock prices. On the other hand, the real activity economists argue that a positive money supply shock will result in an increase in stock values. They debate that a change in the money supply gives information on money demand, which is caused by future income expectations. If the money supply rises, it means that money demand is going up, which, in effect, signals a rise in economic activity. Higher economic activity implies higher cash flows, which induces stock values to increase (Sellin, 2001). Bernanke and Kuttner (2005) discuss the determinations of stock prices which includes the monetary value and the realized risk in holding the stock. A stock is getting more attractive if the perceived risk is low and/or monetary value it bears is high. Money supply affects the monetary value of a stock through its effect on the interest rate. The authors believe that decreasing the money supply raises the real 
interest rate which in turn raises the discount rate, causing a decrease in the value of the stock as argued by the real activity theorists (Bernanke \& Kuttner, 2005). Theoretically, the interest rate has a negative effect on stock market performance because a rise in interest rate would preclude investors making high risk stock market investments compare to low risk interest bearing security investments such as fixed deposits, and treasury bills etc (French et al., 1987). In other words, demand for high risk stock market investments would drop if the interest rate was high. Thus, drop in demand for stocks would finally decrease their values. Nevertheless, given the significance of money in the determination of stock prices, an important question that arises pertains to the efficiency with which stock market participants include the information contained in the growth of money supply into share values. This question is important because if the market is inefficient with respect to the relevant information, then investors can earn consistently higher than normal rates of return. Moreover, it raises serious doubts about the ability of the stock market to perform its main role of transferring funds to the most productive sectors of the economy. The proponents of the efficient market hypothesis hold that all available information is already embedded in the market value of a stock. For this reason, they argue that expected changes in money supply would not affect stock prices and only the unexpected component of a change in money supply would affect them. On the other hand, the opponents of the efficient market hypothesis argue that all available information is not embedded in the prices, and as a consequence, the expected changes in money supply would influence stock prices too (Corrado \& Jordan, 2005). However, some authors who follow on the footfall of the post-Keynesian school of economics have questioned the importance of money supply in affecting stock prices. This school argues that things are in fact the other way around. Changes in the stock market are inducing changes in money supply (Randall, 1998). It is held that change in money supply (M1) reflect the shift of money from long run saving deposits to demand deposits and vice versa as a result of the foregoing changes in stock values. For example, increases in stock prices provide a stimulant to liquidate long-term saving deposits. The received money is then employed in buying stocks and other financial assets. In the process demand deposits tend to increase, which in turn raises money supply (M1). Shostak (2006), argued that the trend is reversed when asset and stock prices are falling. All this means that it is the movement in stock prices that actually cause changes in money supply (M1). If money supply is caused by changes in the stock market, it implies that money supply is not a very good indicator (Shostak, 2006). In short, changes in money supply are simply the manifestation of changes that have already taken place in the stock market.

\section{Data and Empirical Methodology}

\subsection{Data}

This study uses two types of data: annual data for the period from 1985 to 2012, and monthly data that span from January 2000 to December 2013. It was obtained from the U.S. Federal Reserve Bank of Saint Louis and from the Saudi Monetary Agency and the Saudi Capital Market Authority: various issues of Annual Report, Quarterly and Monthly Bulletin. This paper has used different measure of money supply; M1 and M2 because different measures of money supply used can yield different impacts on stock prices Thornton (1993), Ho (1983) and Jones and Uri (1987).

\subsection{Descriptive Statistics}

Table 1. Descriptive statistics

Panel A. Descriptive statistics for annual data

\begin{tabular}{lccc}
\hline & M1(million ) & M2 (million ) & SSPI \\
\hline Mean & 249165.6 & 379433.6 & 3800.106 \\
Median & 148924.5 & 232857.0 & 1993.165 \\
Maximum & 887115.0 & 1211543.0 & 16712.64 \\
Minimum & 83039.00 & 122721.0 & 646.0300 \\
Std. Dev. & 213381.6 & 314778.6 & 3781.497 \\
Correlation coefficient SSPI & 0.56 & 0.6 & 1 \\
\hline
\end{tabular}

Panel B. Descriptive statistics for monthly data

\begin{tabular}{lccc}
\hline & M1 (billion) & M2 (billion) & SSPI \\
\hline Mean & 419 & 631 & 6566.465 \\
Median & 313 & 537 & 6375.080 \\
Maximum & 1000 & 1350 & 19502.65 \\
Minimum & 155 & 240 & 1987.570 \\
\hline
\end{tabular}




\begin{tabular}{lrrc}
\hline Std. Dev. & 249 & 333 & 3565.749 \\
Correlation coefficient SSPI & 0.21 & 0.25 & 1 \\
\hline
\end{tabular}

During the sample period, it is found that the Saudi stock market is highly volatile because standard deviation of SSPI is quite high. According to the table 1 panel A, mean value of the SSPI is 3800 and the standard deviation is 3781.5 for SSPI in the sample, indicating a highly volatile stock market performance. For instance, minimum value of SSPI is reported as 646 and maximum value is reported as 16712.6. The correlation coefficient between SSPI and M2 $(=0.60)$ is greater than the correlation coefficient between SSPI and M1 $(=0.56)$. Table 1 Panel B shows the correlation coefficient between SSPI and M2 in the monthly data $(=0.25)$ is greater than the correlation coefficient between SSPI and M1 $(=0.21)$. The same result has been obtained in the annual data but the difference is that the correlation coefficient is higher in the annual data relative to the monthly data. It seems that the correlation is higher in the long run compared with the short run. However, while the annual data of money supply is more correlated with SSPI, the available annual data for SSPI is not too long to depend on. Therefore, the paper does not rely only on the annual data but also on monthly data.

\subsection{Augmented Dick-Fuller (ADF) Test}

This paper uses Augmented Dicky-Fuller (ADF) test to examine the presence of unit roots in the variables. ADF test is an extended version of the original test of Dicky and Fuller (1979) to control for the serial correlation of the error term (Dicky \& Fuller, 1981). Cointegration in empirical methodology requires variables that are non-stationary in level but stationary after first-differencing. To test whether variables are stationary or not, unit root tests are performed. The time series properties of variables are examined by Dicky and Fuller (DF) or Augmented Dick-Fuller (ADF) unit root test. It is used to determine the order of integration of time series. The test is based on estimates of the following regression equations. For level:

$$
\Delta x_{t}=\propto_{1}+\propto_{2} T+\propto_{3} x_{t-1}+\sum_{i=1}^{p} \propto_{4 i} \Delta x_{t-i}+\varepsilon_{t}
$$

And for first difference:

$$
2_{\Delta} x_{t}=\propto_{1}+\propto_{2} T+\propto_{3} \Delta x_{t-1}+\sum_{i=1}^{p} \propto_{4 i} 2_{\Delta} \mathrm{x}_{\mathrm{t}-\mathrm{i}}+\varepsilon_{t}
$$

Where variable $x_{t}$ the variable is tested for unit root; $\Delta$ is the first difference operator; $\alpha_{1}$. is the constant term; $\mathrm{T}$ is time trend; $\mathrm{p}$ is the number of the lag length which was selected. The null hypothesis is $\mathrm{H}_{0}: \propto_{3}=0$ and the alternative hypothesis $\mathrm{H}_{1}: \propto_{3}<0$. When the absolute value of the calculated t-test is greater than the critical value from Mackinnon (1991), the null hypothesis of the unit root (non-stationary) is rejected, indicating that the variable is stationary at level and integrated of degree zero [I (0)]. However, when the absolute value of the calculated t-test is smaller than the critical value, the null hypothesis of the unit root (non-stationary) is accepted, indicating that the variable is not stationary at their level form and we have to check their stationary for the first difference.

\subsection{Johansen Cointegration Test}

In order to examine the cointegration relationship between the stock market index and the M1 and M2, this study employs widely used Johansen $(1988,1991)$ cointegration test which implement a maximum likelihood procedure. This is because our time series variables are nonstationary in level and stationary after first-differencing. If we find a cointegration between the stock market price index and M1 or M2 variables, it implies that there is a long run relationship between stock market price index and money supply. This methodology tests for the number of cointegration relationships and estimates the parameters of such cointegrating relationships. The cointegration is applied by using vector autoregressive (VAR) model. A general unrestricted VAR model can be represented as the following:

$$
\mathrm{y}_{\mathrm{t}}=A_{0}+\mathrm{A}_{1} \mathrm{y}_{\mathrm{t}-1}+\cdots+\mathrm{A}_{\mathrm{p}} \mathrm{y}_{\mathrm{t}-\mathrm{p}}+\eta_{\mathrm{t}} \mathrm{t}=1,2, \ldots, \mathrm{T}
$$

Where $y_{t}$ is ( $\left.n \times 1\right)$ vector of variables, $\alpha$ is ( $\left.\mathrm{n} \times 1\right)$ vector of constant terms and $\eta_{t}$ is (nx1) vector of usual error term. Equation (3) could be rewritten in the following error correction form:

$$
\Delta y_{t}=A_{0}+\sum_{i=1}^{p-1} \Gamma_{i} \Delta y_{t-i}+\Pi y_{t-1}+\eta_{t}
$$

Where

$$
\Pi=\sum_{i=1}^{p} A_{i}-I \text { and } \Gamma_{i}=-\sum_{j=i+1}^{p} A_{j}
$$

If coefficient matrix $\Pi$ has reduced rank $r<\mathrm{k}$, then there exist $\mathrm{k}$ x $\mathrm{r}$ matrices $\alpha$ and $\beta$ each with rank $\mathrm{r}$ such that 
$\pi=\alpha \beta^{\prime}$ and $\beta y_{t}$ is stationary. Here $\mathrm{r}$ is the number of cointegrating relationships, the elements of $\alpha$ are defined as the adjustment parameters and each column of $\beta$ is a cointegrating vector. The Johansen-Juselius test uses two test statistics through VAR model to identify the number of cointegrating vectors, namely the trace test statistic and the maximum eigen-value test statistic. The test statistic for the trace test is given by:

$$
\text { Trace }=-T \sum_{i=r+1}^{n} \operatorname{In}\left(1-\hat{\lambda}_{i}\right)
$$

The trace test's null hypothesis is $r=0$, cointegrating vectors against the alternative hypothesis of $n$ cointegrating vectors.

The maximum eigenvalue test is given by:

$$
\lambda_{\max }=-T \operatorname{In}\left(1-\hat{\lambda}_{r+1}\right)
$$

This test, on the other hand, tests the null hypothesis of $r$ cointegrating vectors against the alternative hypothesis of $(\mathrm{r}+1)$ cointegrating vectors.

\subsection{Vector Error Correction Model (VECM)}

Once a cointegration relationship is established between variables, a need arises for the construction of an error correction mechanism to model the dynamic relationship. The aim of the error correction model is to indicate the speed of adjustment from the short-run to the long-run equilibrium. A Vector Error Correction Model (VECM) is a restricted VAR model used with non-stationary series that are cointegrated. When equilibrium conditions are imposed, the VECM describes how the model is adjusting in each time period toward its long-run equilibrium. Because the variables are supposed to be cointegrated, any deviation from the long-run equilibrium will feedback in the short run on changes in the dependent variables in order to move toward the long-run equilibrium. According to Engle and Granger (1987), if two series are co-integrated of order one, that is, $I(1)$, then there must exist a VECM representation in order to govern the joint behavior of the series of the dynamic system. For this study, we estimate VECM as follows:

$$
\begin{aligned}
\Delta M 1_{t} & =\propto_{1}+\sum_{i=1}^{p} \propto_{2 i} \Delta M 1_{t-i}+\sum_{i=1}^{n} \propto_{3 i} \Delta S S P I_{t-i}+\sum_{i=1}^{n} \propto_{4 i} \Delta \pi+\propto_{5 i} e_{t-1}+\delta_{1 t} \\
\Delta S S P I_{t} & =\propto_{1}+\sum_{i=1}^{p} \propto_{2 i} \Delta M 1_{t-i}+\sum_{i=1}^{n} \propto_{3 i} \Delta S S P I_{t-i}+\sum_{i=1}^{n} \propto_{4 i} \Delta \pi+\propto_{5 i} e_{t-1}+\delta_{2 t} \\
\Delta M 2_{t} & =\propto_{1}+\sum_{i=1}^{p} \propto_{2 i} \Delta M 2_{t-i}+\sum_{i=1}^{n} \propto_{3 i} \Delta S S P I_{t-i}+\sum_{i=1}^{n} \propto_{4 i} \Delta \pi+\propto_{5 i} e_{t-1}+\delta_{1 t} \\
\Delta S S P I_{t} & =\propto_{1}+\sum_{i=1}^{p} \propto_{2 i} \Delta M 2_{t-i}+\sum_{i=1}^{n} \propto_{3 i} \Delta S S P I_{t-i}+\sum_{i=1}^{n} \propto_{4 i} \Delta \pi+\propto_{5 i} e_{t-1}+\delta_{2 t}
\end{aligned}
$$

where $e_{t-1}$ is the error correction term lagged one period with coefficient $\propto_{5 i}$ measuring the adjustment of model from the short run to the long run and $\delta$ is the white noise. The estimation of the first two equations determines the nature of the relationship between SSPI and M1.

Whether a VAR model in levels or a VECM is a better approach for modeling cointegrated series remains debatable. While the VECM conveniently combines the long-run behavior and short-run interactions of the variables and thus can better reflect the relationship between the variables, the popularity of the VAR model in levels lies in its low computational burden. Moreover, it is still unclear whether the VECM outperforms the VAR model in levels at all forecasting horizons (Naka \& Tufte, 1997). In the literature dealing with short-run dynamic interactions, it seems to be normal to estimate the VAR model in levels for cointegrated variables.

Granger (1986) states that if two variables are stationary of order (1) and cointegrated, then either the first variable leads to the second variable or vice versa. In this study, we use the Granger causality test based on VECM. This provides an additional channel for long-run causality, which is ignored by the Sims and Granger causality tests. Long-run causality is confirmed using the joint significance of the coefficients of lagged variables. A Chi-squared test is employed to check the joint significance of the coefficients of lagged variables and t-tests are used to check for significance of the error term.

\section{Empirical Results}

\subsection{Unit Root Test}

Table 2 panel A shows test results for annual data that do not reject the null hypothesis of unit roots for all variables in level forms because the computed $t$ is smaller than the critical value $(-3.77)$ at $1 \%$ significant level. For the first difference also they are not stationary. However all variables (M1, M2 and SSPI) are only stationary at the second difference indicating that these variables are in fact integrated of order two, I (2). 
Table 2. Unit root test

Panel A. DF-GLS unit root test for annual data

\begin{tabular}{|c|c|c|c|c|c|c|}
\hline variable & $\begin{array}{l}\text { Level with } \\
\text { Constant }\end{array}$ & $\begin{array}{c}\text { Level with } \\
\text { Constant and } \\
\text { Linear Trend }\end{array}$ & $\begin{array}{l}1^{\text {st }} \text { difference } \\
\text { with Constant }\end{array}$ & $\begin{array}{c}1^{\text {st }} \text { difference with } \\
\text { Constant and Linear } \\
\text { Trend }\end{array}$ & $\begin{array}{l}2^{\text {nd }} \text { difference } \\
\text { with Constant }\end{array}$ & $\begin{array}{l}2^{\text {nd }} \text { difference with } \\
\text { Constant and Linear } \\
\text { Trend }\end{array}$ \\
\hline M1 & 0.122273 & -2.148151 & 1.097280 & -1.912062 & $-7.843514 *$ & $-9.164966^{*}$ \\
\hline M2 & -1.070080 & -2.901288 & -0.748683 & -2.834376 & $-5.198156^{*}$ & $-5.824795 *$ \\
\hline SSPI & -2.001197 & -2.918428 & -3.291656 & -3.295056 & $-13.84427 *$ & $-5.599061 *$ \\
\hline
\end{tabular}

Note. * Statistically significant at the $1 \%$ significant level.

Panel B. Augmented Dickey-Fuller unit root test for monthly data

\begin{tabular}{lcc}
\hline variable & Level with Constant and Linear Trend & First difference with Constant and Linear Trend \\
\hline M1 & 0.093169 & $-12.86060^{*}$ \\
M2 & -1.022531 & $-15.64565^{*}$ \\
SSPI & -1.767427 & $-10.40769^{*}$ \\
\hline
\end{tabular}

Note. * Statistically significant at the $1 \%$ significant level.

According to table 2 panel B the variables with monthly data are not stationary at their original level but they are stationary at their first difference.

\subsection{Johansen Cointegration Test}

An appropriate lag length has chosen before applying cointegration technique. Model will be misspecified if the lag length is too small and is over parameterized if the number of lags is too large. The study applies lag order selection based on Akaike Information Criterion (AIC), Final Prediction Error (FPE), Schwarz Criterion (SC), Hannan and Quinn Criterion (HQ) which all suggest lag lengths of two for monthly data and a lag length of one for annual data.

Table 3. Cointegration test between M1 and SSP

\begin{tabular}{|c|c|c|c|c|}
\hline \multicolumn{5}{|c|}{ Panel A: Cointegration test - M1 and SSPI with no trend (Annual Data) } \\
\hline $\mathrm{R}$ & Trace Statistic & 0.05 Critical Value & Max-Eigen Statistic & 0.05 Critical Value \\
\hline None* & 27.26970 & 15.49471 & 26.40386 & 14.26460 \\
\hline At most 1 & 0.865833 & 3.841466 & 0.865833 & 3.841466 \\
\hline \multicolumn{5}{|c|}{ Panel B: Cointegration test - M1 and SSPI with intercept and trend (Annual Data) } \\
\hline $\mathrm{R}$ & Trace Statistic & 0.05 Critical Value & Max-Eigen Statistic & 0.05 Critical Value \\
\hline None* & 31.47941 & 25.87211 & 27.41733 & 19.38704 \\
\hline At most 1 & 4.062082 & 12.51798 & 4.062082 & 12.51798 \\
\hline \multicolumn{5}{|c|}{ Panel C: Cointegration test- M1 and SSPI neither trend nor intercept (Monthly Data) } \\
\hline $\mathrm{R}$ & Trace Statistic & 0.05 Critical Value & Max-Eigen Statistic & 0.05 Critical Value \\
\hline None* & 41.62771 & 12.32090 & 40.12714 & 11.22480 \\
\hline At most 1 & 1.500567 & 4.129906 & 1.500567 & 4.129906 \\
\hline \multicolumn{5}{|c|}{ Panel D: Cointegration test: M1 and SSPI with intercept but no trend (Monthly Data) } \\
\hline $\mathrm{R}$ & Trace Statistic & 0.05 Critical Value & Max-Eigen Statistic & 0.05 Critical Value \\
\hline None* & 22.54349 & 15.49471 & 18.91786 & 14.26460 \\
\hline At most 1 & 3.625633 & 3.841466 & 3.625633 & 3.841466 \\
\hline \multicolumn{5}{|c|}{ Panel E: Cointegration test: M1 and SSPI with intercept and trend (Monthly Data) } \\
\hline $\mathrm{R}$ & Trace Statistic & 0.05 Critical Value & Max-Eigen Statistic & 0.05 Critical Value \\
\hline None * & 29.51594 & 25.87211 & 25.84545 & 19.38704 \\
\hline At most 1 & 3.670494 & 12.51798 & 3.670494 & 12.51798 \\
\hline
\end{tabular}

Note. * denotes rejection of the hypothesis at the 0.05 level.

From Table 3 panel A and B for annual data the study confirms the fact that long run relationship between M1 and SSPI exists. Trace test as well as Max-eigenvalue test indicate one cointegration equation at $5 \%$ level of 
significant. This is true for both with intercept only and with intercept and trend. From Cointegration table 3 panel C, D, and E of monthly data, a rejection of the null hypothesis of no cointegration $(\mathrm{r}=0)$ between SSPI and M1 against the alternative of presence of one or more cointegration at 5\% level of significant is concluded. A trace test as well as Max-eigenvalue test indicates one cointegration equation for all cases. The study concludes a long run relationship between M1 and SSPI.

For the cointegration between SSPI and M2, the lag order selection is based on AIC, FPE, SC, and HQ which all suggest lag lengths of two for monthly data and a lag length of one for annual data. The results of cointegration test are summarized by Table 4 .

Table 4. Cointegration test between M2 and SSPI

\begin{tabular}{|c|c|c|c|c|}
\hline \multicolumn{5}{|c|}{ Panel A: Cointegration test - M2 and SSPI with no trend (Annual Data) } \\
\hline $\mathrm{R}$ & Trace Statistic & 0.05 Critical Value & Max-Eigen Statistic & 0.05 Critical Value \\
\hline None* & 22.41826 & 20.26184 & 19.93017 & 15.89210 \\
\hline At most 1 & 2.488097 & 9.164546 & 2.488097 & 9.164546 \\
\hline \multicolumn{5}{|c|}{ Panel B: Cointegration test - M2 and SSPI with intercept and trend (Annual Data) } \\
\hline $\mathrm{R}$ & Trace Statistic & 0.05 Critical Value & Max-Eigen Statistic & 0.05 Critical Value \\
\hline None & 23.75247 & 25.87211 & 19.23690 & 19.38704 \\
\hline At most 1 & 4.515562 & 12.51798 & 4.515562 & 12.51798 \\
\hline \multicolumn{5}{|c|}{ Panel C: Cointegration test- M2 and SSPI neither trend nor intercept (Monthly Data) } \\
\hline $\mathrm{R}$ & Trace Statistic & 0.05 Critical Value & Max-Eigen Statistic & 0.05 Critical Value \\
\hline None* & 44.42733 & 12.32090 & 42.79503 & 11.22480 \\
\hline At most 1 & 1.632295 & 4.129906 & 1.632295 & 4.129906 \\
\hline \multicolumn{5}{|c|}{ Panel D: Cointegration test: M2 and SSPI with intercept but no trend (Monthly Data) } \\
\hline $\mathrm{R}$ & Trace Statistic & 0.05 Critical Value & Max-Eigen Statistic & 0.05 Critical Value \\
\hline None* & 18.36873 & 15.49471 & 15.46570 & 14.26460 \\
\hline At most 1 & 2.903030 & 3.841466 & 2.903030 & 3.841466 \\
\hline \multicolumn{5}{|c|}{ Panel E: Cointegration test: M2 and SSPI with intercept and trend (Monthly Data) } \\
\hline $\mathrm{R}$ & Trace Statistic & 0.05 Critical Value & Max-Eigen Statistic & 0.05 Critical Value \\
\hline None & 22.88317 & 25.87211 & 18.18516 & 19.38704 \\
\hline At most 1 & 4.698016 & 12.51798 & 4.698016 & 12.51798 \\
\hline
\end{tabular}

Note. * denotes rejection of the hypothesis at the 0.05 level.

From Table 4 panel A for annual data Trace test as well as Max-eigenvalue test indicate one cointegration equation for M2 and SSPI at 5\% level of significant. This cointegration is true with intercept only but not with intercept and trend as it can be seen from Table 4 panels A and B. For monthly data Johansen cointegration test Table 4 panels C, D, and E indicates the cointegration exists between M2 and SSPI when there is neither trend nor intercept and also the case where there is an intercept and no trend. However, the other case which includes intercept with trend, the study accepts the null hypothesis that is no cointegration exist among variables. It is clear that from Johansen Cointegration test with annual data or monthly data the long run relationship between money supply M2 and Saudi Stock Price Index (SSPI) exists and the study confirms long run equilibrium relationship between $\mathrm{M} 2$ and SSPI.

\subsection{Vector Error Correction Models (VECM) Results}

Since the variables of the study are cointegrated, VECM is used to test for the long run and the short run causality. Table 5 summarizes the result of VECM for SSPI and M1. From Table 5 Panel A the results of VECM for the annual data indicate no long run causality running from M1 to SSPI because the sign of the error correction term is not negative. 
Table 5. VECM results for SSPI and M1

Panel A. VECM result for SSPI and M1 with annual data

\begin{tabular}{ccc}
\hline Error Correction & D(SSPI) & D(M1) \\
\hline CointEq1 & 0.036407 & -0.463761 \\
& $(0.01876)$ & $(0.07956)$ \\
& {$[1.94103]$} & {$[-5.82939]$} \\
$\mathrm{D}\left(S S P I_{-1}\right)$ & -0.526585 & -2.063723 \\
& $(0.18744)$ & $(0.79504)$ \\
$\mathrm{D}\left(M 1_{-1}\right)$ & {$[-2.80929]$} & {$[-2.59576]$} \\
& 0.109138 & -0.358803 \\
& $(0.05667)$ & $(0.24035)$ \\
$\mathrm{C}$ & {$[1.92596]$} & {$[-1.49285]$} \\
& -2493.032 & 40628.19 \\
& $(1555.00)$ & $(6595.46)$ \\
& {$[-1.60323]$} & {$[6.16002]$} \\
\hline
\end{tabular}

Panel B. VECM result for SSPI and M1 with monthly data

\begin{tabular}{ccc}
\hline Error Correction & D(SSPI) & D(M1) \\
\hline CointEq1 & $1.09 \mathrm{E}-05$ & -82107.08 \\
& $(0.00159)$ & $(18737.7)$ \\
$D\left(S S P I_{-1}\right)$ & {$[0.00688]$} & {$[-4.38192]$} \\
& 0.192890 & 249836.9 \\
& $(0.07951)$ & $(938802)$ \\
$D\left(S S P I_{-2}\right)$ & {$[2.42608]$} & {$[0.26612]$} \\
& 0.043958 & -477605.1 \\
& $(0.07951)$ & $(938869)$ \\
$D\left(M 1_{-1}\right)$ & {$[0.55284]$} & {$[-0.50870]$} \\
& $7.94 \mathrm{E}-10$ & -0.006932 \\
& $(6.8 \mathrm{E}-09)$ & $(0.08060)$ \\
$D\left(M 1_{-2}\right)$ & {$[0.11636]$} & {$[-0.08600]$} \\
& $2.85 \mathrm{E}-10$ & -0.037212 \\
& $(6.9 \mathrm{E}-09)$ & $(0.08092)$ \\
$\mathrm{C}$ & {$[0.04152]$} & {$[-0.45987]$} \\
& 25.25854 & $5.32 \mathrm{E}+09$ \\
& $(73.3389)$ & $(8.7 \mathrm{E}+08)$ \\
& {$[0.34441]$} & {$[6.14406]$} \\
\hline
\end{tabular}

Note. Standard errors in ( ) \& t-statistics in [ ].

However, the result confirms the long run causality running from SSPI to M1 because the sign of the error correction coefficient to the long-run equilibrium for the equation of M1 is negative and significant. The speed of adjustment is -0.46 which means 46 percent of the short-run deviations from the long run equilibrium is corrected every year.

This study proves that the causality run from SSPI to M1 which indicates the fluctuation of Saudi stock market affect the money supply in Saudi Arabia. This econometric result support the theoretical point of view of the post-Keynesians which states that the causality runs from stock prices to money and not the other way around. Their justification is that increases in stock prices provide an incentive to liquidate long-term saving deposits. The received money is then employed in buying stocks and other financial assets. In other words the long run causal relationship indicates that money supply in Saudi Arabia depends on Saudi stock price index (SSPI). Furthermore, VECM results show bidirectional short run causality between M1 and SSPI. The short run causality result is clear from the coefficient of $\mathrm{D}\left(M 1_{-1}\right)$ in the first equation $\mathrm{D}$ (SSPI) of VECM table which indicates a positive and significant effect of M1 on the change of SSPI. This means as money supply increases, part of the money goes to finance the demand for stocks causing their prices to increase. In the same way, the short run causality result is clear also from the coefficient of $\mathrm{D}(\mathrm{SSPI})$ in the second equation $\mathrm{D}(\mathrm{M} 1)$ which indicates a negative and significant effect of SSPI on the change of M1. The last result implies that as SSPI 
increases, M1 decreases because the money deposits at banks decrease through transferring liquidity to the stock market. The results of monthly data for M1 and SSPI in Table 5 panel B do not show any kind of causality in the long run as well as in the short run.

Table 6. VECM results for SSPI and M2

Panel A. VECM result for SSPI and M2 with annual data

\begin{tabular}{lcc}
\hline Error Correction & D(SSPI) & D(M2) \\
\hline CointEq1 & -0.195202 & 5.884663 \\
& $(0.17488)$ & $(1.22945)$ \\
& {$[-1.11617]$} & {$[4.78643]$} \\
$\mathrm{D}\left(S S P I_{-1}\right)$ & -0.279991 & -2.473260 \\
& $(0.23670)$ & $(1.66399)$ \\
& {$[-1.18291]$} & {$[-1.48634]$} \\
$\mathrm{D}\left(M 2_{-1}\right)$ & 0.025720 & -0.047425 \\
& $(0.03208)$ & $(0.22555)$ \\
$\mathrm{C}$ & {$[0.80166]$} & {$[-0.21027]$} \\
& -635.1390 & 43981.67 \\
& $(1314.13)$ & $(9238.41)$ \\
& {$[-0.48331]$} & {$[4.76074]$} \\
\hline
\end{tabular}

Panel B. VECM result for SSPI and M2 with monthly data

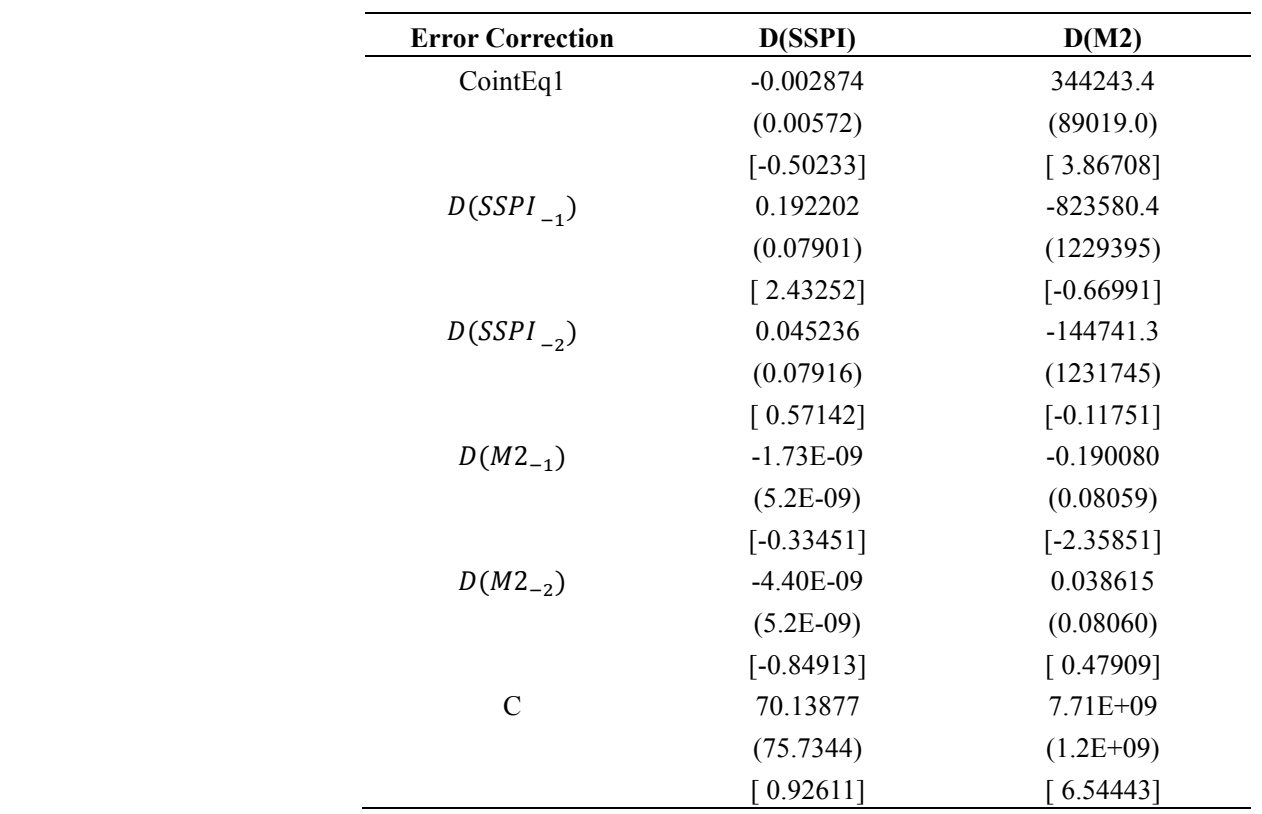

Note. Standard errors in ( ) \& t-statistics in [ ].

Table 6 summarizes the result of VECM for SSPI and M2. From Table 6 Panel A the result of VECM for the annual data indicates no long run causality running from M2 to SSPI because the error correction coefficient is not significant. Also, the result could not confirm long run causality running from SSPI to M2 because the sign of the error correction coefficient for the equation of M2 is not negative even though it is significant. Moreover, VECM results could not show any short run causality between M2 and SSPI. The results of monthly data for M2 and SSPI in table 6 panel B do not show any kind of causality in the long run as well as in the short run.

\section{Conclusion}

This paper has applied cointegration to analyze the relationship of money Supply and Saudi's Stock Price Index (SSPI) using different measure of money supply M1 and M2 and different time series; annual data from 1985 until 2012 and monthly data from 2000 until 2013. The goal is to discover the relationship between them and to identify the long run as well as the short run causality using Vector Error Correction Model (VECM). The results 
suggest that (i) stock price index and money supply is non-stationary in their level form. However, SSPI, M1 and M2 are stationary in the first difference for monthly data and they are stationary in their second difference for annual data, (ii) every form of money supply (M1 or M2) and SSPI are cointegrated suggesting a long run relationship between them. This result holds for both the annual data and monthly data. While this study confirms the positive long run relationship between SSPI and M1 that has been found in the study of Alshogeathri (2011), it finds positive long run relationship between SSPI and M2 which contradicts the finding of Alshogeathri (2011) who discovers a negative long run relationship between SSPI and M2. The result of Alshogeathri can not be supported by the theory. (iii) VECM suggests long run causal relationship that run from SSPI to M1 for annual data but not the other way around which supports the Post-Keynesian finding. This result is not consistent with finding of Kalyanaraman and Al Tuwajri (2014) regarding the long run causality issue. (iv) This result supports the efficient markets hypothesis with respect to M1 and M2 since money supply does not affect the SSPI. Stock market participants incorporate the information contained in the growth of money supply into stock prices. The implication of this result which supports the endogeneity of money supply is that Saudi Arabian Monetary Policy as well as commercial banks can not affect the Saudi Stock prices through change in money supply. (v) VECM indicates short run bidirectional causal relationship (or feedback effect) between SSPI and M1 for annual data. (vi) the study could not confirm any causal relationship between SSPI and M1 for the monthly data. (vii) this paper could not prove any causal relationship between SSPI and M2 for the annual or monthly data.

\section{References}

Alshogeathri, M. A. M. (2011). Macroeconomic determinants of the stock market movements: Empirical evidence from the Saudi Stock market. Doctoral dissertation, Kansas State University.

Aydemir, O., \& Demirhan, E. (2009). The relationship between stock prices and exchange rates evidence from Turkey. International Research Journal of Finance and Economics, 23(2), 207-215.

Bernanke, B. S., \& Kuttner, K. N. (2005). What explains the stock market's reaction to Federal Reserve policy? The Journal of Finance, 60(3), 1221-1257. http://dx.doi.org/10.1111/j.1540-6261.2005.00760.x

Blume, M. R., Kraft, J., \& Kraft, A. (1977). Determinants of common stock prices: A time series analysis. The Journal of Finance, 32(2), 417-425. http://dx.doi.org/10.1111/j.1540-6261.1977.tb03281.x

Brahmasrene, T., \& Jiranyakul, K. (2007). Cointegration and causality between stock index and macroeconomic variables in an emerging market. Academy of Accounting and Financial Studies Journal, 11(3), 17.

Çagli, E. C., Halac, U., \& Taskin, D. (2010). Testing Long-run Relationships between Stock Market and Macroeconomics Variables in the Presence of Structural Breaks: The Turkish Case. International Research Journal of Finance and Economics, 48, 49-60.

Corrado, C. J., \& Jordan, B. D. (2005). Fundamentals of Investments, International Edition.

Dickey, D. A., \& Fuller, W. A. (1979). Distribution of the estimators for autoregressive time series with a unit root. Journal of the American Statistical Association, 74(366a), 427-431. http://dx.doi.org/10.2307/2286348

Dickey, D. A., \& Fuller, W. A. (1981). Likelihood ratio statistics for autoregressive time series with a unit root. Econometrica: Journal of the Econometric Society, 1057-1072. http://dx.doi.org/10.2307/1912517

Enders, W. (1995). Applied econometric time series.

Engle, R. F., \& Granger, C. W. (1987). Co-integration and error correction: Representation, estimation, and testing. Econometrica: Journal of the Econometric Society, 251-276. http://dx.doi.org/10.2307/1913236

Flannery, M. J., \& Protopapadakis, A. A. (2002). Macroeconomic factors do influence aggregate stock returns. Review of Financial Studies, 15(3), 751-782. http://dx.doi.org/10.1093/rfs/15.3.751

French, K. R., Schwert, G. W., \& Stambaugh, R. F. (1987). Expected stock returns and volatility. Journal of Financial Economics, 19(1), 3-29. http://dx.doi.org/10.1016/0304-405X(87)90026-2

Granger, C. W. (1986). Developments in the study of cointegrated economic variables. Oxford Bulletin of Economics and Statistics, 48(3), 213-228. http://dx.doi.org/10.1111/j.1468-0084.1986.mp48003002.x

Granger, C. W. (1988). Some recent development in a concept of causality. Journal of Econometrics, 39(1), 199-211. http://dx.doi.org/10.1016/0304-4076(88)90045-0

Gupta, M. (1974). Money supply and stock market: A probabilistic approach. Journal of Finance and Quantitative Analysis, 9(1). http://dx.doi.org/10.2307/2329968 
Habibullah, M. S. (1998). The Relationship between Broad Money and Stock Prices in Malaysia: An Error Correction Approach. Jurnal Ekonomi Malaysia, 32, 51-73.

Habibullah, M. S., \& Baharumshah, A. Z. (1996). Money, output and stock prices in Malaysia: An application of the cointegration tests. International Economic Journal, 10(2), 121-130. http://dx.doi.org/10.1080/10168739600080015

Ho, Y. K. (1983). Money supply and equity prices: An empirical note on Far Eastern countries. Economics Letters, 11(1), 161-165. http://dx.doi.org/10.1016/0165-1765(83)90179-9

Husain, F., Mahmood, T., \& Azid, T. (1999). Monetary Expansion and Stock Returns in Pakistan. The Pakistan Development Review, 769-777.

Johansen, S. (1988). Statistical analysis of cointegration vectors. Journal of Economic Dynamics and Control, 12(2), 231-254. http://dx.doi.org/10.1016/0165-1889(88)90041-3

Johansen, S. (1991). Estimation and hypothesis testing of cointegration vectors in Gaussian vector autoregressive models. Econometrica: Journal of the Econometric Society, 1551-1580. http://dx.doi.org/10.2307/2938278

Jones, J. D., \& Uri, N. (1987). Money supply growth, stock returns and the direction of causality. Socio-Economic Planning Sciences, 21(5), 321-325. http://dx.doi.org/10.1016/0038-0121(87)90005-X

Kalyanaraman, L., \& Al Tuwajri, B. (2014). Macroeconomic forces and stock prices: Some empirical evidence from Saudi Arabia. International Journal of Financial Research, 5(1), 81. http://dx.doi.org/10.5430/ijfr.v5n1p81

MacKinnon, J. G. (1991). Critical Values for Cointegration Tests. In R. F. Engle \& C. W. J. Granger (Eds.), Long-Run Economic Relationship: Reading in Cointegration. New York: Oxford University Press.

Maskay, B. (2007). Analyzing the effect of change in Money supply on stock prices. The Park Place Economist, 15(1), 72-79.

Maysami, R. C., \& Koh, T. S. (2000). A vector error correction model of the Singapore stock market. International Review of Economics \& $\quad$ Finance, $\quad 9(1), \quad 79-96$. http://dx.doi.org/10.1016/S1059-0560(99)00042-8

Maysami, R. C., Howe, L. C., \& Hamzah, M. A. (2004). Relationship between macroeconomic variables and stock market indices: Cointegration evidence from stock exchange of Singapore's All-S sector indices. Jurnal Pengurusan, 24(1), 47-77.

Mookerjee, R. (1987). Monetary policy and the informational efficiency of the stock market: The evidence from many countries. Applied Economics, 19(11), 1521-1532. http://dx.doi.org/10.1080/00036848700000081

Naka, A., \& Tufte, D. (1997). Examining impulse response functions in cointegrated systems. Applied Economics, 29(12), 1593-1603. http://dx.doi.org/10.1080/00036849700000035

Pallegedara, A. (2012). Dynamic Relationships between Stock Market Performance and Short Term Interest Rate-Empirical Evidence from Sri Lanka. http://dx.doi.org/10.2139/ssrn.2156150

Poire, N. P. (2000). The money effect. Barron's business and financial weekly magazine: August.

Rapach, D. E., Wohar, M. E., \& Rangvid, J. (2005). Macro variables and international stock return predictability. International Journal of Forecasting, 21(1), 137-166. http://dx.doi.org/10.1016/j.ijforecast.2004.05.004

Sellin, P. (2001). Monetary policy and the stock market: Theory and empirical evidence. Journal of Economic Surveys, 15(4), 491-541. http://dx.doi.org/10.1111/1467-6419.00147

Shaoping, C. (2008). Positivist analysis on effect of monetary policy on stock price behaviors. In Proceedings of 2008 conference on regional economy and sustainable developmentm.

Shostak, F. (2003). Making sense of money supply data. Ludwig von Mises Institute Daily Article. 17th December.

Shostak, F. (2006). Money and the Stock Market: What is the Relation? Mises Daily.

Sorensen, E. H. (1982). Rational expectations and the impact of money upon stock prices. Journal of Financial and Quantitative Analysis, 17(05), 649-662. http://dx.doi.org/10.2307/2330854

Sprinkel, B. W. (1964). Money and stock prices. Homewood, Ill: RD Irwin.

Thornton, J. (1993). Money, output and stock prices in the UK: Evidence on some (non) relationships. Applied Financial Economics, 3(4), 335-338. http://dx.doi.org/10.1080/758534946 
Wray, L. R. (1998). Modern Money. Working Paper No.252 September 1998, The Jerome Levy Economics Institute. http://dx.doi.org/10.2139/ssrn.137409

\section{Copyrights}

Copyright for this article is retained by the author(s), with first publication rights granted to the journal.

This is an open-access article distributed under the terms and conditions of the Creative Commons Attribution license (http://creativecommons.org/licenses/by/3.0/). 